\title{
Pengaruh Game Edukasi Kahoot! Terhadap Penguasaan Konsep Mahasiswa Calon Guru Sekolah Dasar Pada Materi Perpindahan Kalor
}

\author{
Muhammad Erfan ${ }^{1}$, Mohammad Archi Maulyda ${ }^{2}$ \\ Program Studi PGSD FKIP Universitas Mataram ${ }^{1,2}$ \\ muhammaderfan@unram.ac.id ${ }^{1}$, archimaulyda@unram.ac.id ${ }^{2}$
}

\begin{abstract}
Abstrak
Penelitian ini bertujuan untuk mengetahui perbedaan penguasaan konsep mahasiswa calon guru sekolah dasar pada materi perpindahan kalor menggunakan game edukasi Kahoot! pada kelas yang belajar dengan metode ceramah melalui webmeeting pada perkuliahan daring. Penelitian ini merupakan penelitian eksperimen semu dengan desain pretest-posttest control group. Sampel pada penelitian ini diambil dengan cluster random sampling dan diperoleh kelas 5A sebagai kelas eksperimen yaitu kelas yang belajar melalui webmeeting pada perkuliahan daring disertai game edukasi Kahoot! dan kelas 5E sebagai kelas kontrol yang belajar dengan metode ceramah melalui webmeeting pada perkuliahan daring. Data dalam penelitian ini diperoleh dengan teknik tes dan dianalisis dengan uji-t sampel independent. Hasil penelitian menunjukkan bahwa terdapat perbedaan yang signifikan pada nilai ratarata posttest pemahaman konsep mahasiswa calon guru sekolah dasar di kelas eksperimen dan kelas kontrol. Nilai rata-rata posttest pemahaman konsep mahasiswa pada kelas eksperimen lebih tinggi daripada kelas kontrol sehingga game edukasi Kahoot! berpengaruh positif dalam meningkatkan pemahaman konsep mahasiswa calon guru sekolah dasar pada materi perpindahan kalor.
\end{abstract}

Kata kunci: game, edukasi, kahoot, konsep, kalor 


\section{PENDAHULUAN}

Merebaknya wabah virus corona (Covid-19) hingga menyebabkan pandemi berdampak pada berbagai sektor yang tidak hanya pada sektor ekonomi yang meliputi jatuhnya nilai tukar rupiah serta harga-harga barang kebutuhan pokok yang naik tetapi juga berdampak pada perubahan perilaku pada tatanan kehidupan yang sifatnya lebih luas (psikologis, sosial, keamanan, serta politik) dan dalam jangka waktu yang lebih panjang (Rosali, 2020). Bidang pendidikan yang mencakup kegiatan proses belajar mengajar juga terdampak oleh adanya pandemi ini di mana proses kegiatan belajar mengajar lebih besar dilakukan secara dalam jaringan (daring).

Banyak tantangan yang dihadapi pendidik selama kegiatan pembelajaran daring mulai dari pendidik dan peserta didik harus terbiasa melakukan interaksi pembelajaran jarak jauh, kegiatan pembelajaran yang terintegrasi dengan teknologi informasi, kuota komunikasi yang harus tersedia, signal internet yang harus mumpuni, serta media pembelajaran harus berupa media audio visual yang mengupayakan keaktifan peserta didik. Semua tantangan tersebut harus diupayakan pendidik melalui pembelajaran daring sehingga pendidik dituntut untuk berpikir kreatif dan inovatif dalam menciptakan lingkungan maupun media pembelajaran agar materi pembelajaran dapat tersampaikan dan tujuan pembelajaran dapat tercapai secara maksimal.

Salah satu upaya yang dapat dilakukan oleh pendidik agar kegiatan proses belajar mengajar selama masa pandemi dapat berjalan sesuai dengan rencana pelaksanaan pembelajaran adalah dengan memperkaya cara menyampaikan materi pembelajaran selain yang biasa disampaikan melalui web meeting. Cara penyampaian materi pembelajaran dapat juga dilakukan dengan memberikan materi konsep-konsep melalui permainan digital mengingat selama proses pembelajaran dalam jaringan, peserta didik tidak dapat lepas dari gadget sebagai alat utama dalam proses pembelajaran.

Peserta didik generasi baru $\mathrm{Z}$ yang lahir pada era digital dan tidak dapat dipisahkan dengan penggunaan teknologi informasi dan komunikasi dalam kehidupan sehari-hari (Anastasiadis et al., 2018; Vivianti, 2018). Peserta didik generasi baru ini telah terbiasa menggunakan informasi digital dalam kegiatan sehari-hari dan selalu terhubung satu sama lain melalui jaringan digital, bekerja secara interaktif, kadang dapat mengerjakan beberapa tugas secara berkolaborasi jarak jauh, serta tidak hanya untuk bermain game dalam waktu yang lebih lama dari generasi sebelumnya tetapi juga peserta didik generasi baru ini menikmati kegiatan dalam dunia digital (Beck \& Wade, 2006; Huizenga et al., 2009). Terbiasanya peserta didik generasi baru dalam dunia digital merupakan kesempatan bagi 
pendidik dalam menyampaikan materi pembelajaran dengan wahana gadget yang salah satunya melalui pembelajaran berbasis permainan digital atau digital game-based learning.

Digital game based learning merupakan pembelajaran yang melibatkan permainan digital yang menggabungkan konten pendidikan atau prinsip-prinsip pembelajaran ke dalam video game dengan tujuan agar peserta didik dapat terlibat aktif (Erfan \& Ratu, 2017). Selain itu digital game-based learning juga didesain untuk menyeimbangkan konten pembelajaran dengan konten permainan yang selanjutnya dapat menilai kemampuan pembelajar apakah telah menguasai dan mampu mengaplikasikan pengetahuannya dalam dunia nyata (Rivera, 2016).

Kegiatan yang melibatkan permainan dalam kegiatan pembelajaran tidak hanya memberikan dampak positif tetapi juga dapat memberikan dampak negatif. Video games dapat meningkatkan motivasi dan daya konsentrasi peserta didik (Cardoso-Leite \& Bavelier, 2014). Bermain game juga dapat meningkatkan kreativitas pemain (Blanco-Herrera et al., 2019), serta permainan tertentu selain dapat meningkatkan hasil belajar peserta didik (Dewantara et al., 2020) juga dapat meningkatkan kemampuan pemecahan masalah peserta didik (Granic et al., 2014; Iswinarti \& Suminar, 2019). Dampak negatif dari bermain game di antaranya adalah dapat menyebabkan kontrol emosi yang tidak stabil pada peserta didik (Quwaider et al., 2019), dari sisi kesehatan, terlalu banyak bermain game dapat menyebabkan gangguan penglihatan (visual) dan juga dapat menyebabkan kegemukan (Ayenigbara, 2018). Memberikan waktu terlalu banyak bermain game pada peserta didik menyebabkan peserta didik menjadi kecanduan dalam bermain game (Grüsser et al., 2007). Oleh karena itu, dalam mengintegrasikan permainan dalam kegiatan pembelajaran, pendidik juga harus memperhatikan dan mempertimbangkan efek positif dan negatif dalam pembelajaran yang melibatkan media berupa permainan atau game.

Salah satu konsep dasar IPA yang harus dikuasai oleh calon pendidik sekolah dasar adalah konsep perpindahan kalor (panas). Konsep perpindahan kalor penting untuk dipelajari dan ditanamkan pada calon pendidik sekolah dasar selain masalah dalam konsep perpindahan kalor ini sering dialami dalam kehidupan sehari-hari juga membekali calon pendidik sekolah dasar dengan konsep perpindahan kalor yang benar sehingga peserta didik tidak salah konsep mengenai perpindahan kalor. Konsep perpindahan kalor yang dipelajari meliputi terjadinya perpindahan kalor karena adanya perbedaan temperatur dan proses perpindahan kalor berdasarkan medium perantara perpindahan kalor (konduksi, konveksi, dan radiasi). Pembelajaran mengenai konsep perpindahan kalor ini umumnya didemonstrasikan melalui praktik langsung dan pemberian kuis setelahnya, namun karena 
adanya pandemi covid-19 memaksa pendidik untuk menanamkan konsep perpindahan kalor dengan media pembelajaran lainnya.

Media yang dapat digunakan untuk memberikan kuis agar pembelajaran dalam jaringan dapat berjalan secara interaktif adalah dengan Game Edukasi Kahoot!. Game edukasi Kahoot! merupakan salah satu platform permainan online yang bisa digunakan untuk kegiatan belajar mengajar di dalam kelas baik kelas luring maupun daring. Game edukasi Kahoot! Dapat diakses secara gratis dan dapat dikatakan mudah dalam pengoperasiannya. Selain itu game Edukasi Kahoot! memiliki beberapa fitur yaitu quiz, jumble, discussion, dan survei yang dapat menjadi pilihan dalam membuat kegiatan pembelajaran menjadi lebih menarik dan lebih melibatkan peserta didik dalam proses pembelajaran (Setiawati et al., 2019).

Menimbang pentingnya penanaman konsep perpindahan kalor pada mahasiswa calon pendidik sekolah dasar dan adanya keuntungan pembelajaran dengan memanfaatkan game, oleh karena itu peneliti berkeinginan untuk meningkatkan pemahaman konsep mahasiswa calon guru sekolah dasar pada materi perpindahan kalor melalui game edukasi Kahoot!.

\section{METODE PENELITIAN}

Penelitian ini merupakan penelitian kuantitatif dengan pendekatan kuasi eksperimen dan desain penelitian yang digunakan adalah pretest-posttest control group. Penelitian ini bertujuan untuk meningkatkan pemahaman konsep mahasiswa calon guru sekolah dasar pada materi perpindahan kalor menggunakan game edukasi Kahoot!. Konsep perpindahan kalor yang dibelajarkan adalah konsep perbedaan temperatur dan konsep perpindahan kalor berdasarkan medium perpindahannya (proses konduksi, konveksi dan radiasi).

Permainan atau Game Edukasi pada penelitian ini memanfaatkan fitur quiz. Pembelajaran konsep perpindahan kalor dilaksanakan dengan cara (1) Dosen membuat akun gratis di website Kahoot! yang nantinya juga dapat terhubung dengan akun google (2) Dosen membuat fitur dan materi soal yang mengukur kemampuan pemahaman konsep mahasiswa calon guru sekolah dasar pada materi perpindahan kalor (3) Setelah materi selesai dibuat, pengajar memberikan pin yang diberikan akses oleh Kahoot! dan meminta mahasiswa mengakses laman website https://kahoot.it untuk memasukakan pin serta username (4) Perangkat utama pengajar akan menampilkan pertanyaan yang berupa pilihan ganda, (5) Mahasiswa memilih jawaban yang sesuai dari perangkat yang ada pada sesuai dengan durasi waktu yang telah ditentukan (akan lebih menarik dan memudahkan menggunakan smartphone) (6) Peserta didik yang memilih menjawab paling cepat dan tepat akan mendapatkan nilai yang lebih tinggi, secara kompetitif (7) Diakhir permainan pengajar dapat 
menyimpan hasil jawaban dari masing-masing peserta didik di google drive atau langsung di unduh pada komputernya dalam bentuk spreadsheet, sebagai evaluasi penilaian, agar lebih menarik pengajar juga dapat memberikan reward ke peserta didik yang mendapatkan skor tertinggi.

Populasi pada penelitian ini adalah seluruh mahasiswa calon guru sekolah dasar semester lima di salah satu perguruan tinggi negeri di Kota Mataram yang berjumlah 284 orang mahasiswa. Teknik pengambilan sampel yang digunakan adalah cluster random sampling dan diperoleh kelas 5A (34 mahasiswa) sebagai kelas eksperimen yaitu kelas yang belajar konsep perpindahan kalor dengan game edukasi Kahoot!, dan 5E (31 mahasiswa) sebagai kelas kontrol yaitu kelas konvensional yang belajar konsep perpindahan kalor tanpa menggunakan game edukasi Kahoot!. Data mengenai pemahaman konsep mahasiswa diperoleh dengan tes pilihan ganda. Data pada penelitian ini selain dianalisis dengan uji-t sampel independen.

\section{HASIL DAN PEMBAHASAN}

Sebagai uji prasyarat analisis dilakukan pretest terhadap kemampuan awal mahasiswa calon guru sekolah dasar pada materi konsep perpindahan kalor. Hasil pretest disajikan pada Tabel 1.

Tabel 1. Rata-rata Nilai Pretest pada Kelas Kontrol dan Kelas Eksperimen

\begin{tabular}{ccccc}
\hline Kelas & Rata-rata & Normalitas & Homogenitas & Signifikansi \\
\hline Eksperimen & 52,72 & Sig. $0,422>0,05$ & Sig. $0,358>0,05$ & t-hitung $<$ t-tabel \\
Kontrol & 50,56 & Sig. $0,251>0,05$ & & $0,780<1,669$ \\
& & & & Sig. (2-tailed) \\
& & & $0,438>0,05$ \\
& & & Tidak berbeda \\
& & & signifikan \\
\hline
\end{tabular}

Hasil kemampuan awal mahasiswa calon guru sekolah dasar pada materi konsep perpindahan kalor seperti yang ditunjukkan pada Tabel 1 diketahui bahwa nilai rata-rata pretest mahasiswa di kelas eksperimen $(52,72)$ dan kelas kontrol $(50,56)$. Dari hasil tersebut diketahui bahwa kemampuan kedua kelas ini hampir sama dan masing-masing berada dalam kategori sedang. Berdasarkan hasil uji Normalitas pada Tabel 1 diketahui bahwa nilai signifikansi Shapiro-Wilk pada kelas eksperimen diperoleh nilai Sig. 0,422 >0,05 dan untuk kelas kontrol diperoleh nilai signifikansi Sig. 0,251 >0,05. Kedua nilai signifikansi tersebut menunjukkan bahwa data kemampuan awal mahasiswa calon guru dalam penguasaan konsep 
perpindahan kalor semuanya terdistribusi normal. Hasil uji homogenitas untuk melihat apakah nilai pretest pada kelas eksperimen maupun kelas kontrol memiliki varian yang sama, dan diperoleh nilai signifikansi di atas 0,05 (Sig. 0,358 > 0,05) yang berarti bahwa data kemampuan awal (pretest) mahasiswa calon guru sekolah dasar pada konsep perpindahan antara kedua kelas (eksperimen dan kontrol) memiliki varian data yang sama atau homogen.

Selanjutnya dilakukan uji-t independent sample pada data pretest dan hasilnya menunjukkan bahwa t-hitung < t-tabel $(0,780<1.669)$ dan nilai Sig (2-tailed) $0,438>0,05$ yang berarti bahwa tidak terdapat perbedaan signifikan antara rata-rata nilai pretest pemahaman konsep perpindahan kalor antara kelas eksperimen dan kelas kontrol.

Tabel 2. Rata-rata Nilai Posttest pada Kelas Kontrol dan Kelas Eksperimen

\begin{tabular}{ccccc}
\hline Kelas & Rata-rata & Normalitas & Homogenitas & Signifikansi \\
\hline Eksperimen & 75,74 & Sig. $0,260>0,05$ & Sig. $0,499>0,05$ & t-hit $>$ t-tabel \\
Kontrol & 55,66 & Sig. $0,359>0,05$ & & $7,343>1,669$ \\
& & & Sig. (2-tailed) \\
& & & $0,000<0,05$ \\
& & & Berbeda \\
& & & signifikan \\
\hline
\end{tabular}

Hasil analisis data pada Tabel 2 menunjukkan bahwa nilai rata-rata posttest kemampuan mahasiswa calon guru sekolah dasar dalam memahami konsep perpindahan kalor setelah diberikan perlakukan pada kelas eksperimen sebesar 75,74 dan kelas kontrol sebesar 55,66. Selanjutnya dilakukan uji-t terhadap nilai posttest pemahaman konsep mahasiswa setelah diberi perlakuan dan hasilnya menunjukkan bahwa nilai t-hitung > t-tabel $(7,343>1,669)$ yang menunjukkan bahwa terdapat perbedaan yang signifikan antara nilai rata-rata posttest pemahaman konsep perpindahan kalor di kelas eksperimen dan kelas kontrol.

Perbandingan hasil pretest dan posttest dan peningkatan pemahaman konsep perpindahan kalor pada mahasiswa calon guru sekolah dasar pada kelas eksperimen dan kelas kontrol dapat dilihat pada Gambar 1. 


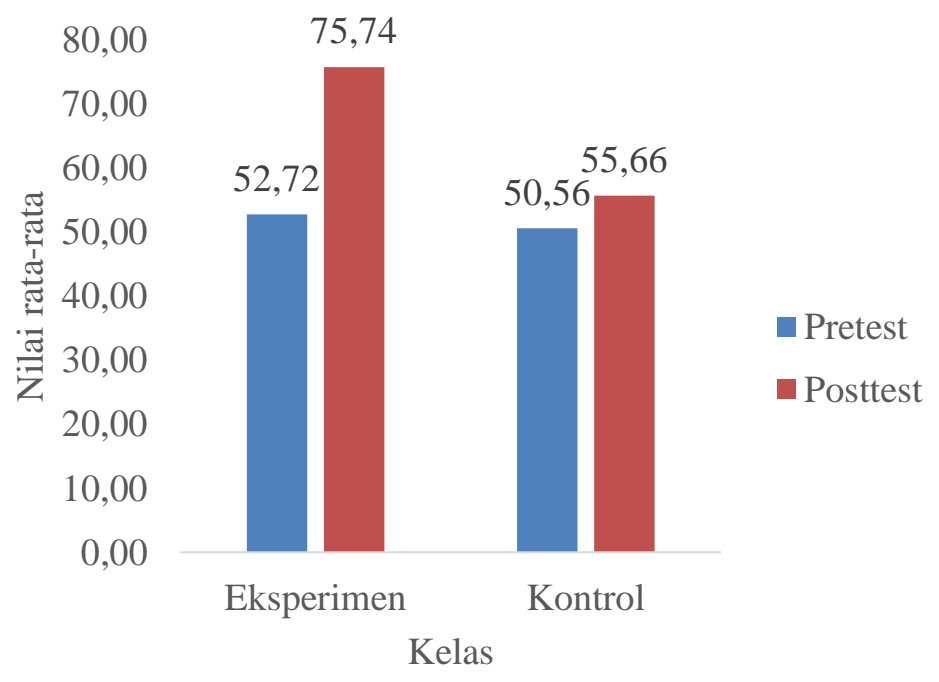

Gambar 1. Perbandingan hasil pretest dan posttest mahasiswa

Berdasarkan Gambar 1 dapat diketahui bahwa pada masing-masing kelas baik kelas eksperimen maupun kelas kontrol sama-sama mengalami peningkatan pada penguasaan konsep perpindahan kalor. Mahasiswa calon guru sekolah dasar pada kelas eksperimen mengalami peningkatan pemahaman konsep perpindahan kalor yang lebih tinggi daripada mahasiswa calon guru sekolah dasar yang berada pada kelas kontrol. Meningkatnya pemahaman mahasiswa calon guru sekolah dasar pada konsep perpindahan kalor pada kelas eksperimen juga dikuatkan oleh hasil uji-t pada nilai posttest kedua kelas (eksperimen dan kontrol) dimana t-hitung lebih besar dari t-tabel dengan t-hitung sebesar 7,343 dan t-tabel sebesar 1,669 pada taraf signifikansi 5\%. Hasil uji-t mengindikasikan bahwa terdapat perbedaan yang signifikan antara nilai rata-rata pemahaman konsep mahasiswa calon guru sekolah dasar setelah diberikan perlakuan (posttest). Berdasarkan Gambar 1 juga diketahui bahwa kelas eksperimen mengalami peningkatan nilai rata-rata kemampuan mahasiswa calon guru dalam penguasaan konsep perpindahan kalor yang lebih tinggi daripada kelas kontrol. Hal ini mengindikasikan bahwa pembelajaran IPA pada materi konsep perpindahan kalor dengan game edukasi Kahoot! lebih memberikan dampak positif.

Adanya perbedaan kemampuan mahasiswa calon guru dalam penguasaan konsep perpindahan kalor setelah diberikan perlakuan berupa belajar melalui permainan atau game juga didukung oleh penelitian terdahulu di mana pembelajaran melalui permainan atau game simulasi dapat memberikan pengaruh positif terhadap penguasaan konsep peserta didik (Dewantara et al., 2020; M Erfan et al., 2020; Ratu \& Erfan, 2017).

Pembelajaran IPA pada materi konsep perpindahan kalor dengan game edukasi Kahoot! lebih memberikan dampak positif karena dengan adanya game quiz dengan limit 
waktu ditambah dengan adanya pemberian reward bagi peserta didik yang memperoleh nilai tertinggi tentunya juga berpengaruh dalam meningkatkan motivasi peserta didik dalam belajar (Hartanti, 2019; Irwan et al., 2019; Putri et al., 2019; Wichadee \& Pattanapichet, 2018; Wigati, 2019). Adanya game edukasi berupa Kahoot! dapat dimungkinkan mampu meningkatkan kemampuan peserta didik dalam berpikir cepat dan tepat yang tentu saja dapat dijadikan topik penelitian selanjutnya.

\section{KESIMPULAN}

Hal yang dapat disimpulkan dari penelitian ini adalah terdapat perbedaan yang signifikan antara nilai rata-rata pemahaman konsep sifat-sifat cahaya pada mahasiswa calon guru sekolah dasar setelah belajar dengan permainan atau game edukasi Kahoot! Penggunaan Game edukasi Kahoot! dalam proses pembelajaran efektif dalam meningkatkan pemahaman konsep mahasiswa calon guru pada materi konsep perpindahan kalor.

\section{DAFTAR PUSTAKA}

Anastasiadis, T., Lampropoulos, G., \& Siakas, K. (2018). Digital Game-based Learning and Serious Games in Education. International Journal of Advances in Scientific Research and Engineering, 4(12), 139-144. https://doi.org/10.31695/IJASRE.2018.33016

Ayenigbara, I. (2018). Gaming Disorder and Effects of Gaming on Health: An Overview. Journal of Addiction Medicine and Therapeutic Science, 001-003. https://doi.org/10.17352/2455-3484.000025

Beck, J., \& Wade, M. (2006). The Kids are Alright: How the Gamer Generation is Changing the Workplace. Harvard Business School Press.

Blanco-Herrera, J. A., Gentile, D. A., \& Rokkum, J. N. (2019). Video Games can Increase Creativity, but with Caveats. Creativity Research Journal, 31(2), 119-131. https://doi.org/10.1080/10400419.2019.1594524

Cardoso-Leite, P., \& Bavelier, D. (2014). Video game play, attention, and learning. Current Opinion in Neurology, 27(2), 185-191. https://doi.org/10.1097/WCO.0000000000000077

Dewantara, D., Wati, M., Misbah, M., Mahtari, S., \& Haryandi, S. (2020). The Effectiveness of Game Based Learning on The Logic Gate Topics. Journal of Physics: Conference Series, 1491, 012045. https://doi.org/10.1088/1742-6596/1491/1/012045

Erfan, M, Maulyda, M. A., Gunawan, G., Sari, N., \& Ratu, T. (2020). Enhancing Students Ability in Analyzing Image Formation on Lens and Mirror Using Ray Optics. Journal of Physics: Conference Series, 1471, 012061. https://doi.org/10.1088/1742$6596 / 1471 / 1 / 012061$

Erfan, Muhammad, \& Ratu, T. (2017). Meningkatkan Minat Dan Hasil Belajar Mahasiswa Pada Perkuliahan Elektronika Dasar Melalui Digital Game-Based Learning. 
Meningkatkan Minat Dan Hasil Belajar Mahasiswa Pada Perkuliahan Elektronika Dasar Melalui Digital Game-Based Learning, 332-337. https://doi.org/S09628924(12)00067-0 [pii] \n10.1016/j.tcb.2012.04.004

Granic, I., Lobel, A., \& Engels, R. C. M. E. (2014). The benefits of playing video games. American Psychologist, 69(1), 66-78. https://doi.org/10.1037/a0034857

Grüsser, S. M., Thalemann, R., \& Griffiths, M. D. (2007). Excessive Computer Game Playing: Evidence for Addiction and Aggression? CyberPsychology \& Behavior, 10(2), 290-292. https://doi.org/10.1089/cpb.2006.9956

Hartanti, D. (2019). Meningkatkan Motivasi Belajar Siswa dengan Media Pembelajaran Interaktif Game Kahoot Berbasis Hypermedia. Prosiding Seminar Nasional PEP 2019, $78-85$.

Huizenga, J., Admiraal, W., Akkerman, S., \& Dam, G. ten. (2009). Mobile game-based learning in secondary education: engagement, motivation and learning in a mobile city game. Journal of Computer Assisted Learning, 25(4), 332-344. https://doi.org/10.1111/j.1365-2729.2009.00316.x

Irwan, I., Luthfi, Z. F., \& Waldi, A. (2019). Efektifitas Penggunaan Kahoot! untuk Meningkatkan Hasil Belajar Siswa [Effectiveness of Using Kahoot! to Improve Student Learning Outcomes]. PEDAGOGIA: Jurnal Pendidikan, 8(1), 95. https://doi.org/10.21070/pedagogia.v8i1.1866

Iswinarti, I., \& Suminar, D. R. (2019). Improving Children's Problem-Solving Skills Through Javanese Traditional Games. Jurnal Cakrawala Pendidikan, 38(3), 578-589. https://doi.org/10.21831/cp.v38i3.25331

Putri, B. R., Safitri, D., \& Sujarwo, S. (2019). Penggunaan Media Kahoot! untuk Meningkatkan Hasil Belajar IPS. Edukasi IPS, 3(2), 27-36.

Quwaider, M., Alabed, A., \& Duwairi, R. (2019). The Impact of Video Games on the Players Behaviors: A Survey. Procedia Computer Science, 151, 575-582. https://doi.org/10.1016/j.procs.2019.04.077

Ratu, T., \& Erfan, M. (2017). The Effect of Every Circuit Simulator to Enhance Motivation and Students Ability in Analyzing Electrical Circuits. 2nd Asian Education Symposium, 399-404. https://doi.org/10.5220/0007305103990404

Rivera, M. (2016). Is Digital Game-Based Learning The Future Of Learning? ELearning Industry. https://elearningindustry.com/digital-game-based-learning-future

Rosali, E. S. (2020). Aktifitas Pembelajaran Daring pada Masa Pandemi Covid-19 di Jurusan Pendidikan Geografi Universitas Siliwangi Tasikmalaya. Jurnal GEOSEE, 1(1), 21-30.

Setiawati, H. D., Sihkabuden, S., \& Adi, E. P. (2019). Pengaruh Kahoot! Terhadap Hasil Belajar Siswa Kelas XI di SMAN 1 Blitar. Jurnal Kajian Teknologi Pendidikan, 1(4), 273-278.

Vivianti, V. (2018). Digital Teaching and Learning Bermuatan Pendidikan Karakter: Strategi Mengajar Untuk Digital Natives. Prosiding "Profesionalisme Guru Abad XXI," 127 134.

Wichadee, S., \& Pattanapichet, F. (2018). Enhancement of Performance and Motivation Through Application of Digital Games in An English Language Class. The Journal of 
Teaching English with Technology, 18(1), 77-92.

Wigati, S. (2019). Penggunaan Media Game Kahoot Untuk Meningkatkan Hasil dan Minat Belajar Matematika. AKSIOMA: Jurnal Program Studi Pendidikan Matematika, 8(3). https://doi.org/10.24127/ajpm.v8i3.2445 